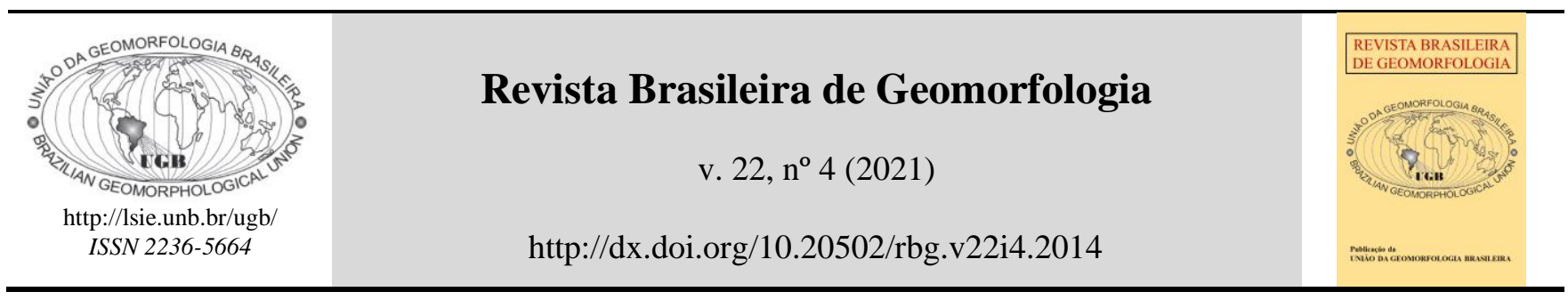

Artigo de Pesquisa

\title{
Why do large rivers tend to form multichannel? A field study in the Upper Paraná River
}

\author{
Por que grandes rios tendem à canalização múltipla? Um estudo de campo no \\ rio Paraná Superior
}

\section{José C. Stevaux ${ }^{1}$, Priscila P. Gon ${ }^{2}$, Isabel T. Leli ${ }^{3}$, and Rafaela H. Fujita ${ }^{4}$}

${ }^{1}$ Graduate Program in Geography, Universidade Federal do Mato Grosso do Sul - Campus de Três Lagoas, MS, Brazil. josecstevaux@gmail.com.

ORCID: https://orcid.org/0000-0001-6136-2556.

${ }^{2}$ Graduate Program in Geoscience and Environment. UNESP/IGCE - Rio Claro, SP, Brazil. pripg@hotmail.com.

ORCID: https://orcid.org/0000-0002-0088-0795.

${ }^{3}$ Graduate Program in Geography, Western State of Paraná, UNIOESTE/Marechal Cândido Rondon, PR, Brazil. isabeltleili@gmail.com.

ORCID: https://orcid.org/0000-0002-4344-3739.

${ }^{4}$ Graduate Program in Geography of the State University of Western Paraná (UNIOESTE/ Francisco Beltrão, R, Brazil. rafaela.fujita@gmail.com.

Recebido: 03/09/2020; Aceito: 05/10/2020; Publicado: 01/10/2021

\begin{abstract}
Anastomosed rivers include a diverse group of fluvial forms with multiple and interconnected alluvial channels. They occur in a wide range of climates and reliefs and constitute the typical pattern of the mega rivers $\left(\right.$ Qm $\left.>17,000 \mathrm{~m}^{3} \mathrm{~s}^{-1}\right)$. Several authors have assumed that the development of an anabranching formation is the mechanism by which a channel maintains its maximum efficiency. However, this has only been tested by mathematical studies. In this study, we confirm this theory in a 58$\mathrm{km}$ anabranching reach of the Upper Paraná River, through a hydraulic and bathymetric survey of 14 cross-sections. We conclude that where the slope can't increase, the channel reduces its $w: d$ ratio, thereby maintaining its efficiency in the wider sections, according to the specific stream power equation $(\omega=\rho g Q s / w)$. The channel width and alluvial plain width are controlled by allochthonous factors (tectonic lineaments and bank composition). Although the nodal sections have the greatest efficiency, we confirmed that flow efficiency is maintained at a constant level of bedload transport and specific stream power along the anabranching reach.
\end{abstract}

Keywords: anabranching river, large river, specific stream power, Paraná River, maximum efficiency concept.

Resumo: Os rios anastomosados incluem um grupo diverso de padrões fluviais de rios com canais aluviais múltiplos e interconectados. Ocorrem em uma ampla gama de climas e relevos e constituem o padrão típico dos mega-rios $\left(\mathrm{Qm}>17.000 \mathrm{~m}^{3}\right.$ 
$\left.\mathrm{s}^{-1}\right)$. Vários autores afirmam que a multicanalização é o mecanismo pelo qual o rio canal mantém sua eficiência máxima. No entanto, isso só foi testado, até o momento, por estudos matemáticos. Neste estudo, confirmamos esta teoria em um trecho multicanal de $58 \mathrm{~km}$ do Alto Rio Paraná, por meio de um levantamento hidráulico e batimétrico de 14 seções transversais. Concluímos que onde não é possível o aumento da pendente, o canal reduz sua relação w:d, mantendo, dessa forma, sua eficiência nas seções mais largas, de acordo com a equação de potência de fluxo específica ( $\omega=$ @gQs / w). A largura do canal e a largura da planície aluvial são controladas por fatores alóctones (lineamentos tectônicos e composição do banco). Embora as seções nodais tenham a maior eficiência, confirmamos que a eficiência do fluxo é mantida em um nível constante de transporte de carga de fundo e potência de fluxo específica ao longo do trecho multicanal.

Palavras-chave: padrão multicanal, padrão anastomosado, potência de fluxo específica, rio Paraná, conceito de eficiência máxima.

\section{Introduction}

Although relatively common in the literature, studies on multichannel rivers are normally focused on short stretches of small rivers (NANSON and KNIGHTON, 1996; KNIGHTON, 1998; NANSON and HUANG, 1999, 2008; JANSEN and NANSON, 2004; JANSEN and NANSON, 2010). Latrubesse (2008) presented the first general study of large rivers, concluding that anabranching is the only possible channel geometry for rivers beyond the threshold of Qm 17,000 $\mathrm{m}^{3} \mathrm{~s}^{-1}$ (mega-rivers). According to Latrubesse (2008), among the ten largest rivers in the world, nine are anabranching and five have part of their basin in Brazil: the Amazonas, Madeira, Japurá, Negro, and Paraná. This fact emphasizes the need for the studies on hydraulics and sediment transport, at a time when this country has an aggressive policy on hydroelectric exploitation, conducted without real knowledge of dams' impacts on large fluvial systems (STEVAUX, PINTO, MEURER, 2009; LATRUBESSE et al., 2017). The Paraná, for instance, is probably the most heavily dammed of the world's large river basins (with approximately 150 large dams), and numerous Amazonian large rivers are in the Brazilian hydroelectric matrix. Two dams (Santo Antônio and Jirau) have recently begun operation on the Madeira River, which is responsible for $50 \%$ of the water and sedimentary load entering the Amazon River Basin (MEADE et al., 1983; MARTINELLI et al. 1993; FILIZOLA and GUYOT, 2009), and there are approximately two dozen dams planned on its tributaries. The impact of these dams reaches not only the Lower Amazon River but extends to the Atlantic Ocean and includes geomorphological, ecological, and climatic disturbances (LATRUBESSE et al., 2017).

Anastomosed rivers include a diverse range of river forms with multiple and interconnected alluvial channels, separated by stable, vegetated islands, which divide the flow the bankfull stage (NANSON and KNIGHTON, 1996; KNIGHTON, 1998; NANSON and HUANG, 1999). They can be found in a wide range of climatic and relief conditions, from the glacial to tropical zones and from lowlands to mountains. Although Nanson and Knighton (1996) have presented a six-fold classification for anastomosed rivers, Latrubesse (2008) postulated that it is possible to recognize three patterns for large anabranching (anastomosed) rivers:

1) The low sinuosity anabranching pattern: this is the case for the Solimões, Amazon, and Madeira rivers. Rivers of this pattern have a low anastomosing rate (normally with no more than three sub-channels) and the islands are generally associated with bends whose diameter is larger than the width of a single main channel.

2) The anabranching-tending-toward-braided pattern: rivers in this group have a high bedload compared with the former group and present more than five sub-channels (high anabranching rate) and sand bars that evolve into islands (LELI, 2015; LELI, STEVAUX, ASSINE, 2020). The Paraná and Brahmaputra belong to this group. 
3) The mega-complex anabranching pattern: like the Congo between Mobenga and Mokangamoi, and the Negro River at the Anavilhanas and Murai Archipelagos, these are rivers of more than $10 \mathrm{~km}$ width, with a high anastomosing rate and large islands.

Huang and Nanson (2000) postulated that island formation and consequent channel anabranching is a mechanism for maintaining maximum efficiency. However, Leli, Stevaux, and Assine (2020) suggested that while this is valid in the case of islands formed from central bars, the formation of floodplain-excised islands is linked to other factors not yet well understood. Herein, we discuss only anabranching formed by in-channel processes.

Huang and Nanson $(2002,2007)$ demonstrated mathematically, using the maximum flow efficiency concept (MFEC), that the channel slope controls the formation of a multichannel pattern. However, it is possible to identify other control factors in the literature, such as (a) fine sediment overbank deposition (WENDE and NANSON, 1998), (b) dense riparian vegetation (TOOTH and NANSON, 1999; JANSEN and NANSON, 2010), and (c) valley width (TOOTH and NANSON, 2004). Jansen and Nanson (2004) stated that anabranching increases sediment transportation compared to a single-channeled river with the same total width. This was contested by Tabata and Hickin (2003), and Abbado, Slingerland, and Smith (2005) concerning the Columbia River, Canada. However, these studies have two limitations: they are small fluvial systems, and they have developed under semi-arid and subglacial climates, respectively. The assumptions valid for smaller rivers often do not apply to larger ones. Large rivers are characterized by very low slopes, and their bed load is formed by fine to medium sand; they extend for more than a thousand kilometers from the ocean, and their hydrological dynamics are completely different in terms of flood wave transmission (COMUNELLO, SOUZA FILHO, ROCHA, 2002), floodplain construction (LATRUBESSE, 2004; STEVAUX and SOUZA, 2004, PARKER and LATRUBESSE, 2004), and especially geomorphological history (STEVAUX, 1994; POTTER and HUMBLIN, 2006). With low slopes and low specific stream power $\left(\omega<20 \mathrm{~W} \mathrm{~m}^{-2}\right)$, but large water and sediment discharges, large rivers need to maximize their efficiency.

Herein, we present an analysis of the hydraulic parameters of a $58 \mathrm{~km}$ long anabranching stretch of the Upper Paraná River $\left(\mathrm{Qm}=9000 \mathrm{~m}^{3} \mathrm{~s}^{-1}\right)$ to answer the following questions:

a) Can the river maintain its flow efficiency even as the channel widens?

b) Is there a relationship between channel widening and multichannel formation?

c) What, in this case, study, controls channel widening?

d) How do morphological (w:d and s) and hydraulic ( $q b, Q b s, \Omega$, and $\omega$ ) relationships change as a function of the number of channels, and is there a relationship with the flow efficiency?

\section{Regional and local setting}

The study area is an anastomosed reach of the Upper Paraná River between the Porto São José $\left(22^{\circ} 45^{\prime} 52^{\prime \prime}\right.$ S;

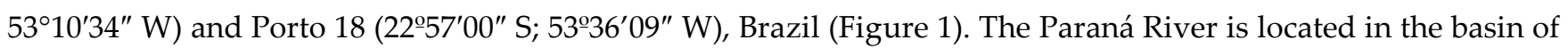
the River Plate, with an area of approximately $3 \times 10^{6} \mathrm{~km}^{2}$, of which $45.6 \%$ is in Brazil, $29.7 \%$ in Argentina, $13.2 \%$ in Paraguay, $6.6 \%$ in Bolivia, and 4.8\% in Uruguay (ORFEO and STEVAUX, 2002). 


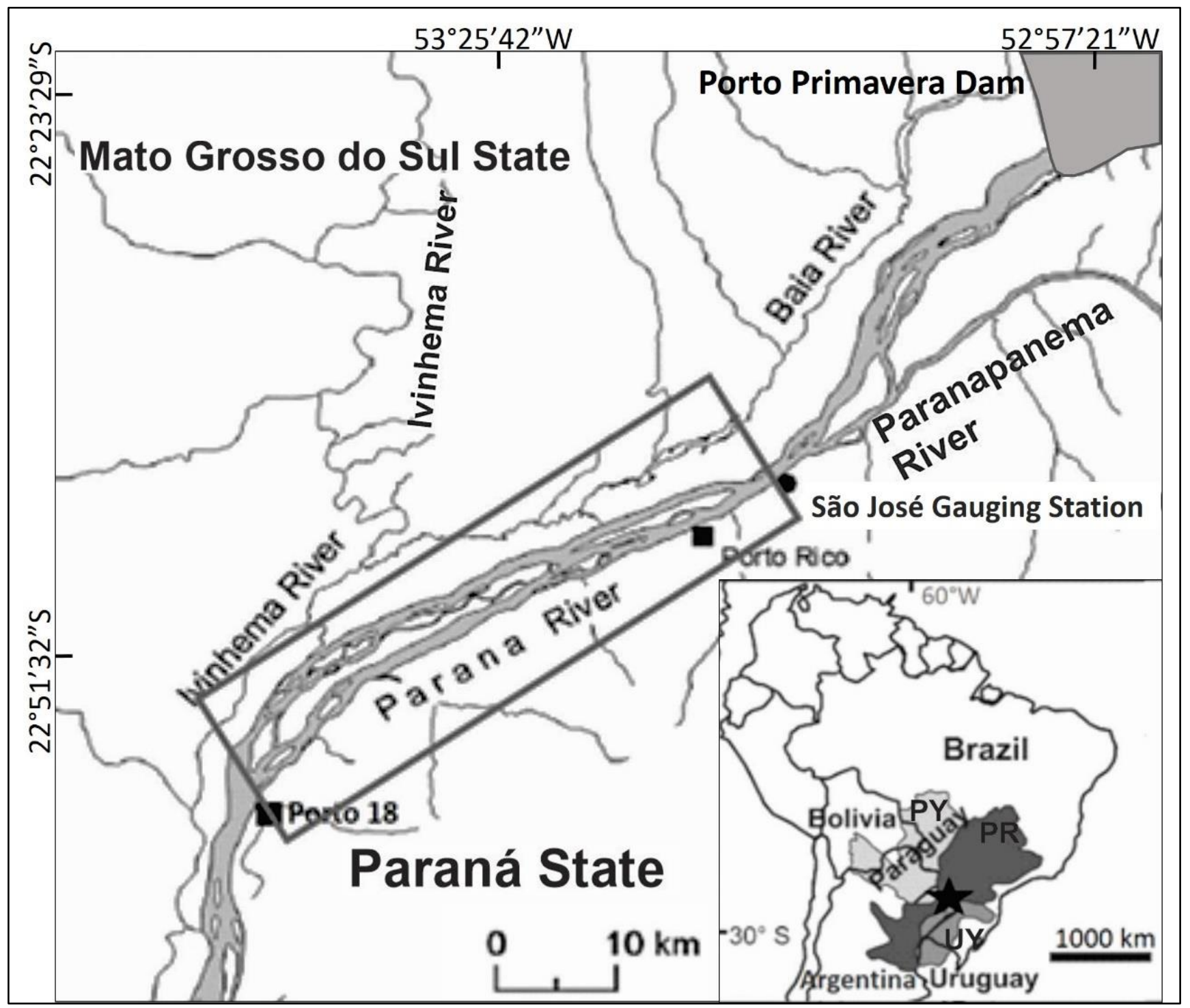

Figure 1. Location of the study area. Bottom right: La Plata Basin (Paraná + Paraguay + Uruguay Basins). The star marks the study area. PR, PY, UY = Paraná, Paraguay, Uruguay River Basins.

At the study reach, the Paraná River drains an area of $800 \times 10^{3} \mathrm{~km}^{2}$, including more than 150 large dams (STEVAUX, CORRADINI, AQUINO, 2009). The proper Paraná River has only $235 \mathrm{~km}$ of non-dammed conditions, where we conducted this work. Although considerably impacted by dams, the reach has a huge database developed over almost four decades of study on ecology, hydrology, and Quaternary evolution (THOMAZ, AGOSTINHO, HAN, 2004). The Porto São José fluvial station (Figure 1), in operation since 1963, recorded Qm = $9,000 \mathrm{~m}^{3} \mathrm{~s}^{-1}, \mathrm{Qbf}=17,000 \mathrm{~m}^{3} \mathrm{~s}^{-1}$, with extremes of 4,200 and 30,000 $\mathrm{m}^{3} \mathrm{~s}^{-1}$ (STEVAUX, 1994; ORFEO and STEVAUX, 2004).

The alluvial plain in the study reach is asymmetric, with the river channel drifted to the left margin and an 8 $\mathrm{km}$ wide floodplain developed only on the right side. Two terraces occur on the right side of the alluvial valley, at 10 and $18 \mathrm{~m}$ above the current floodplain level. The occurrence of the hard, eolian, sandstone of the Caiuá Formation (K) produces a steep 10 to $20 \mathrm{~m}$ high left bank in the study reach. Since the beginning of the Holocene, the river has been building a complex floodplain (STEVAUX, 1994; LELI, 2015) formed by island annexation, channel abandonment, and vertical overbank accretion (STEVAUX and SOUZA, 2004). 
The climate is tropical to subtropical with a monthly average temperature higher than $15^{\circ} \mathrm{C}$ and annual rainfall of $1500 \mathrm{~mm}$ (IBGE, 1990). The riparian vegetation consists of macrophytes, grasses, and shrubs in the floodplain and island, and trees along the natural levees (SOUZA-STEVAUX, ROMAGNOLO, PREVIDELLO, 1995). The creation of the State Natural Park of "Ilhas e Várzeas do Ivinhema" in the 2000s promoted the recovery of former agricultural and pasture areas (STEVAUX et al., 2013).

The Upper Paraná is developed over the Paleozoic-Mesozoic intra-cratonic Paraná Sedimentary Basin. The NW-SE and NE-SW systems of structural lineament control the drainage pattern of the upper river basin so that the main tributaries are oriented by the NW-SE lineaments, and the trunk-river by NW-SW normal fault system (MAACK, 1981; STEVAUX, 1994). Although tectonically stable since the end of the Mesozoic (ALMEIDA, 1976), some minor reactivations have occurred in the area since the end of the Miocene (FORTES, STEVAUX, VOLKMER, 2005; FRANCO, ETCHBEHERE, STEVAUX, 2008; SOUZA JR. et al., 2013) (Figure 2).

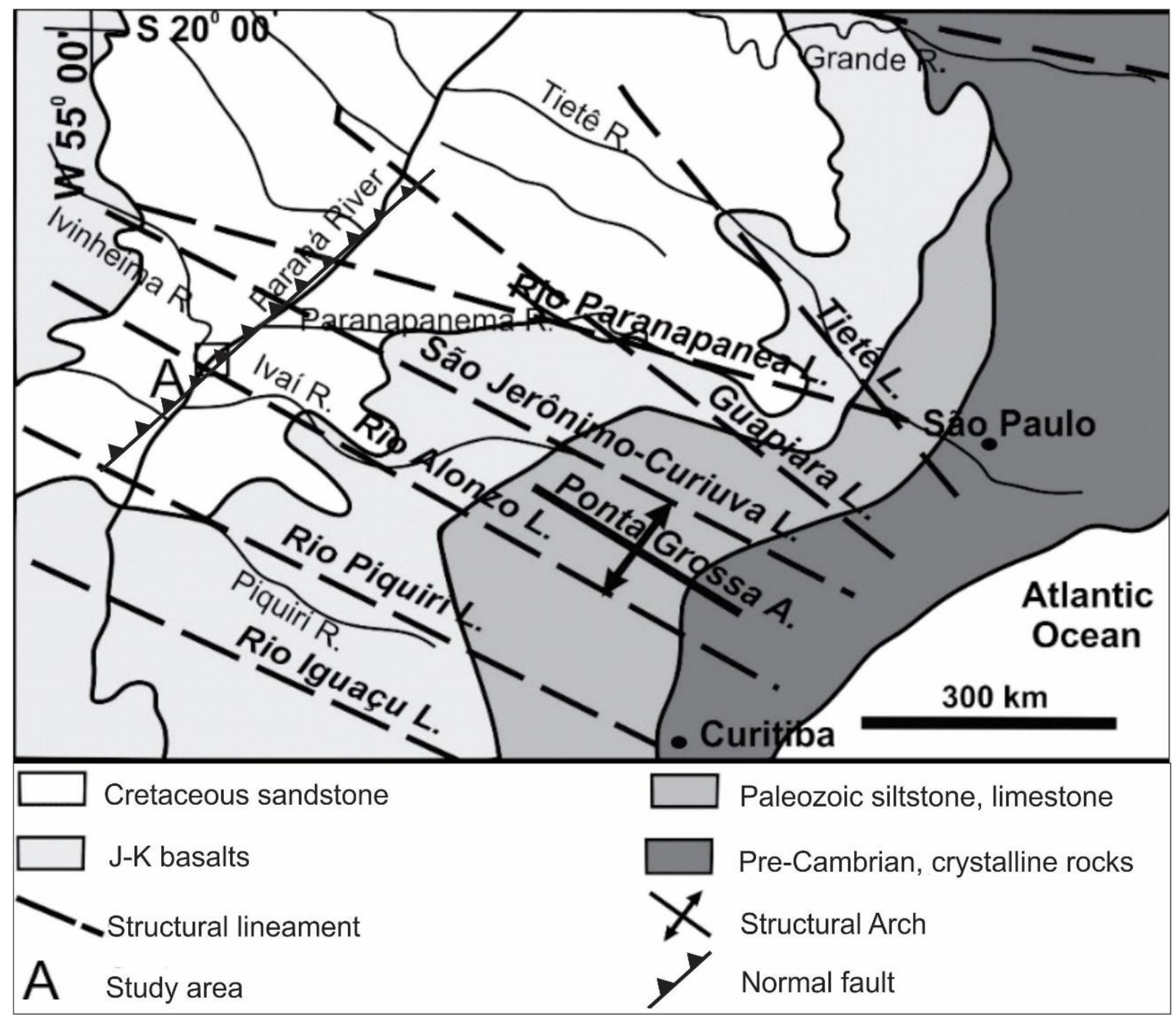

Figure 2. Simplified geological and structural map of the Upper Paraná River area. NW-SE structural lineament systems control the main tributary distribution, and are responsible for knickpoints and nodal sections in the Paraná River (STEVAUX, 1994). The Rio Alonzo Lineament System (FULFARO et al., 1982) crosses the study reach (see detail in Figure 5). A NE-SW normal fault controls the path of the trunk river (MAACK, 1968). 
The study reach is delimitated by the nodal sections of Porto São José (upstream) and Porto 18. The anabranching pattern results from approximately 50 islands of different sizes, grouped in the Mutum and Japonesa-Floresta Archipelagos (Figure 3). The islands are very stable in their morphology and have a centennial to millennial permanence in the channel. Leli, Stevaux, and Assine (2018), for instance, estimated the age of formation of Mutum Island at 8 ka BP $\left({ }^{14} \mathrm{C}\right.$ years). Corrêa and Souza Filho (2005), based on a 40-year historical series of aerial photographs and satellite images, developed an erosion-deposition map for the same reach. Using this map, we estimated the erosion to sedimentation rate for the Mutum, Japonesa, and Floresta islands as 1.08. Stevaux (1994) observed that the presence of the regional NW Rio Alonzo Lineaments System (FULFARO et al., 1982) defines the size of anabranching by the nodal section of Porto São José and Porto 18.

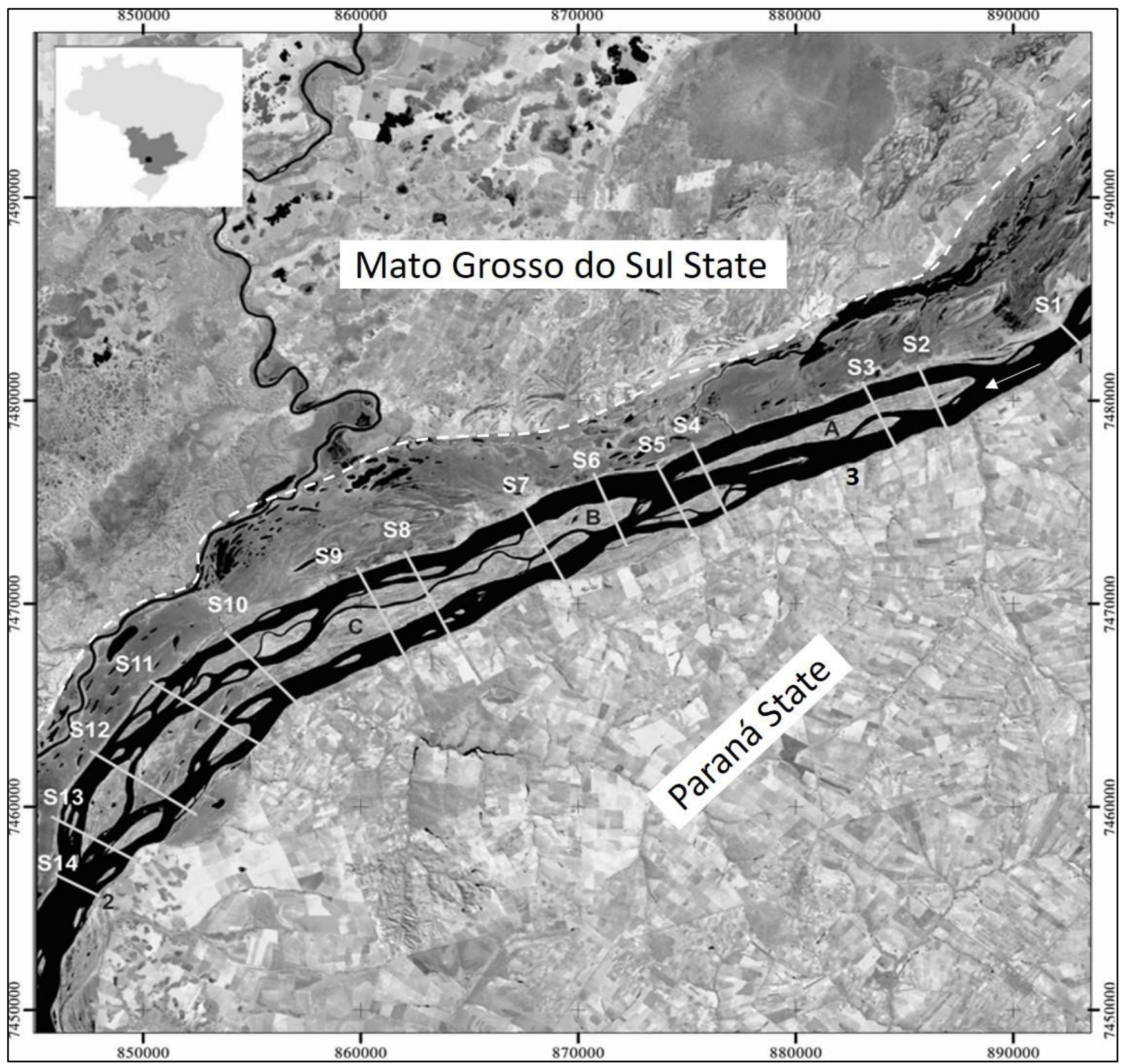

Figure 3. Upper Paraná River at the study reach. The river pattern is anabranching, with (A) Mutum Island, (B) Japonesa Island, and (C) Floresta Islands. S1 to S14 are the surviving cross-sections. 1 is Porto São José (gauging station), 2 is Porto 18, and 3 is Porto Rico. The dashed line is the limit of the Paraná River floodplain and the alluvial terrace on the right bank. 
Stevaux et al. (2009) described the main hydraulic and hydrological modifications introduced into the study reach by the construction of the Porto Primavera dam, which closed in 2000 (Figure 1). The authors concluded that, although dam construction has compromised, the original characteristics of the reach in terms of discharge regime and the transportation of sedimentary load, the morphology of its runoff structure (e.g., channels, islands, and natural levees) were not modified from the pre-dam conditions (CORRÊA and SOUZA FILHO, 2005; LELI, STEVAUX, ASSINE, 2018), allowing their evaluation and the measurements presented herein.

\section{Methods}

The list of symbols and unities is in Table 1.

Table 1. List of symbols and units.

\begin{tabular}{|c|c|c|}
\hline $\mathrm{v}$ & flow velocity $\left(\mathrm{m} \mathrm{s}^{-1}\right)$ & flow velocity average $\left(\mathrm{m} \mathrm{s}^{-1}\right)$ \\
\hline $\mathrm{d}$ & channel depth (m) & slope \\
\hline $\mathrm{n}$ & Manning's coefficient (roughness) & Q, Qs water density, and sediment density $\left(\mathrm{kg} \mathrm{m}^{3}\right)$ \\
\hline & gravity $\left(\mathrm{m} \mathrm{s}^{-2}\right)$ & $\mathrm{Q}, \mathrm{Qm}$ discharge, and discharge average $\left(\mathrm{m}^{3} \mathrm{~s}^{-1}\right)$ \\
\hline $\mathrm{w}$ & channel width (m) & Qbf bankfull discharge $\left(\mathrm{m}^{3} \mathrm{~s}^{-1}\right)$ \\
\hline$q b$ & unity bed-load discharge $\left(\mathrm{m}^{3} \mathrm{~s}^{-1} \mathrm{~m}^{-1}\right)$ & bedload discharge by section $\left(\mathrm{t} \mathrm{d}^{-1}\right)$ \\
\hline S & channel sinuosity & Qbc $\quad$ bedload discharge per channel $\left(\mathrm{t} \mathrm{d}^{-1}\right)$ \\
\hline $\mathrm{T}$ & transport parameter & shear velocity related to the bed $\left(\mathrm{m} \mathrm{s}^{-1}\right)$ \\
\hline & hydraulic radius & critical shear velocity for grain movement \\
\hline & Chezy coefficient (related to grain) & grain diameter at $\mathrm{x} \%(\mathrm{~mm})$ \\
\hline i & bed slope & specific density $\left(\mathrm{Q}_{\mathrm{s}} / \mathrm{Q}\right)$ \\
\hline$\Omega$ & stream power $(\mathrm{W})$ & unity stream power $\left(\mathrm{W} \mathrm{m}^{-2}\right)$ \\
\hline $\mathrm{p}$ & bed sediment porosity $=0.4$ & dune shift velocity $\left(\mathrm{m} \mathrm{d}^{-1}\right)$ \\
\hline $\mathrm{D}^{*}$ & grain parameter & dune morphological coefficient \\
\hline $\mathrm{H}$ & dune average height $(\mathrm{m})$ & \\
\hline
\end{tabular}

We surveyed 14 sections (Figure 3) with different degrees of anabranching (numbers of channels per section), using the Doppler effect acoustic profiler (ADCP) and the FURUNO echo-sound. For each section, we obtained the flow velocity and direction, instantaneous discharge, and channel bathymetry. We collected bed-load samples in the left, center, and right of each cross-section using a Petersen/van Veen sampler and submitted these to grainsize analysis. We also made a general sedimentary description of the banks of each surveyed section. The hydraulic parameters used in this study were obtained as follows:

Slope. We calculated the water surface slope using the Manning Equation (DIETRICH, DAY, PARKER, 1999):

$$
V=R h^{0^{\prime} 67} S^{\underline{0} 5} / n \quad \rightarrow \quad s=\left(v n d^{o^{\prime} 67}\right)^{2}
$$

We also used slope data from the literature, estimated by DGPS survey (LELI, 2015) and by conventional topographic survey (MARTONI and LESSA, 1999) for the same reach.

Stream power and unit stream power. The stream power is the energy of the system to perform the work: carrying water and sediment, eroding margins, etc. The unit or specific stream power is the stream power per unit channel section area (BAGNOLD, 1966, 1977) according to the following equations:

$$
\begin{gathered}
\Omega=\rho g Q s \\
\omega=(\rho g Q s) / w
\end{gathered}
$$

Bedload transport. For bedload transport determination, we used the method of Van Rijn (1984) (Eq. 4). This method has been successfully used for bedload transport estimation in the Lower Paraná River (AMSLER, PRENDE, AND 
ROMANO, 2000) and in this reach (MARTINS and STEVAUX, 2005; MARTINS, 2008). The authors gauged the equation based on the empirical data of bedform migration velocity. We used the BEDLOAD 1.0xlsx software elaborated by Macedo et al. (2017) for bedload transport.

$$
\frac{q b}{[(s-1) g]^{1 / 2} D_{50} 1,5}=0,053 \frac{T^{2,1}}{D * 0,3}
$$

where

$$
\begin{gathered}
T=\left[\left(u^{*^{\prime}}\right)^{2}-\left(u_{c r}^{*}\right)^{2}\right] /\left[\left(u_{c r}^{*}\right)^{2}\right], \\
u^{* \prime}=(g \bar{v})^{0.5} / C^{\prime} \\
u_{c r}^{*}=(g R h i)^{0,5} \\
C^{\prime}=18 \log \left(12 R h / 3 D_{90}\right) \\
D^{*}=D_{50}\left[\left\{(\varsigma-1) g / v^{2}\right\}\right]^{1 / 3}
\end{gathered}
$$

$\mathrm{qb}$ is in $\mathrm{m}^{3} \mathrm{~s}^{-1}$ by $\mathrm{m}$ of section, and $\mathrm{Qb}$ is in $\mathrm{t}^{-1}$, so that $\mathrm{Qb}=\mathrm{qb} \mathrm{w} \varrho_{\mathrm{s}}$, and $\varrho_{\mathrm{s}}=(1-\mathrm{p})$ Qquartz (AMSLER et al., 2000). We also compared the bedload values obtained by Martins and Stevaux (2005) for the same reach using the dune migration method, based on the following equation:

$$
q b=(1-p) H k u d
$$

\section{Analysis and results}

\subsection{Bank characteristics and planform morphometry}

The Paraná River presents three types of banks in the study reach (Figure 4). (1) The left banks are mostly constituted by the rocks of the Caiuá Formation (K), consisting of well-sorted, fine to medium, reddish-yellow, quartzose sandstone, with large-scale cross-stratification typical of aeolian deposits. The Caiuá sandstone is very hard and resistant to erosion owing to its intensive silica and iron oxide cement; this results in a 20-m high, vertical bank. The presence of the NW normal fault has induced the development of a generally straight pattern to the river in the study reach. However, the sinuosity of the smaller secondary channels is higher and increases with decreasing channel width (Figure 5). (2) Banks formed by a homogenous sequence of relatively cohesive reddishbrown mud. This type of bank is also resistant to erosion. (3) Highly erosive mixed banks, formed by the intercalation of layers of massive, reddish-brown mud and white medium to fine sand. Fernandez (1990) described intensive erosion of this type of bank by block fall, with an erosion rate of up to $17 \mathrm{~m} \mathrm{y}^{-1}$.

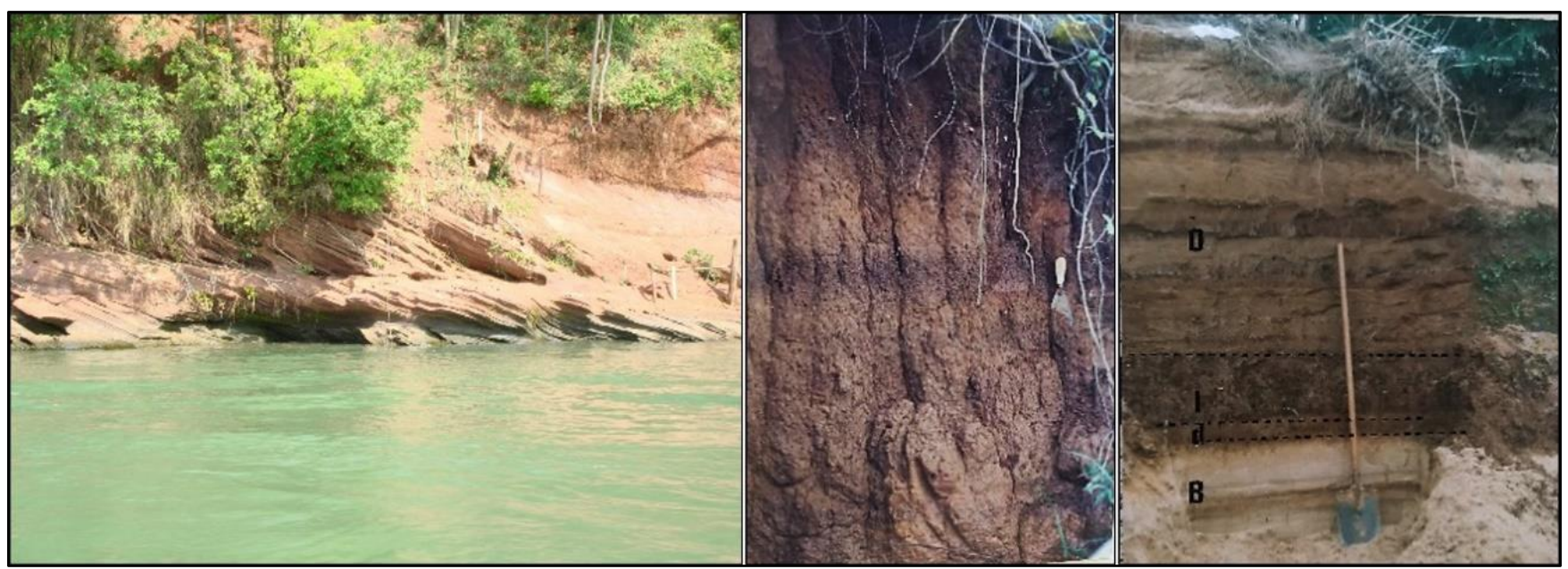

Figure 4. Banks of the Upper Paraná River in the study reach: (L) left vertical bank formed by the sandstone of the Caiuá Fm.; 
(M) homogenous cohesive muddy bank; (R) mixed bank formed by the intercalation of friable sand and mud layers of high erodibility.

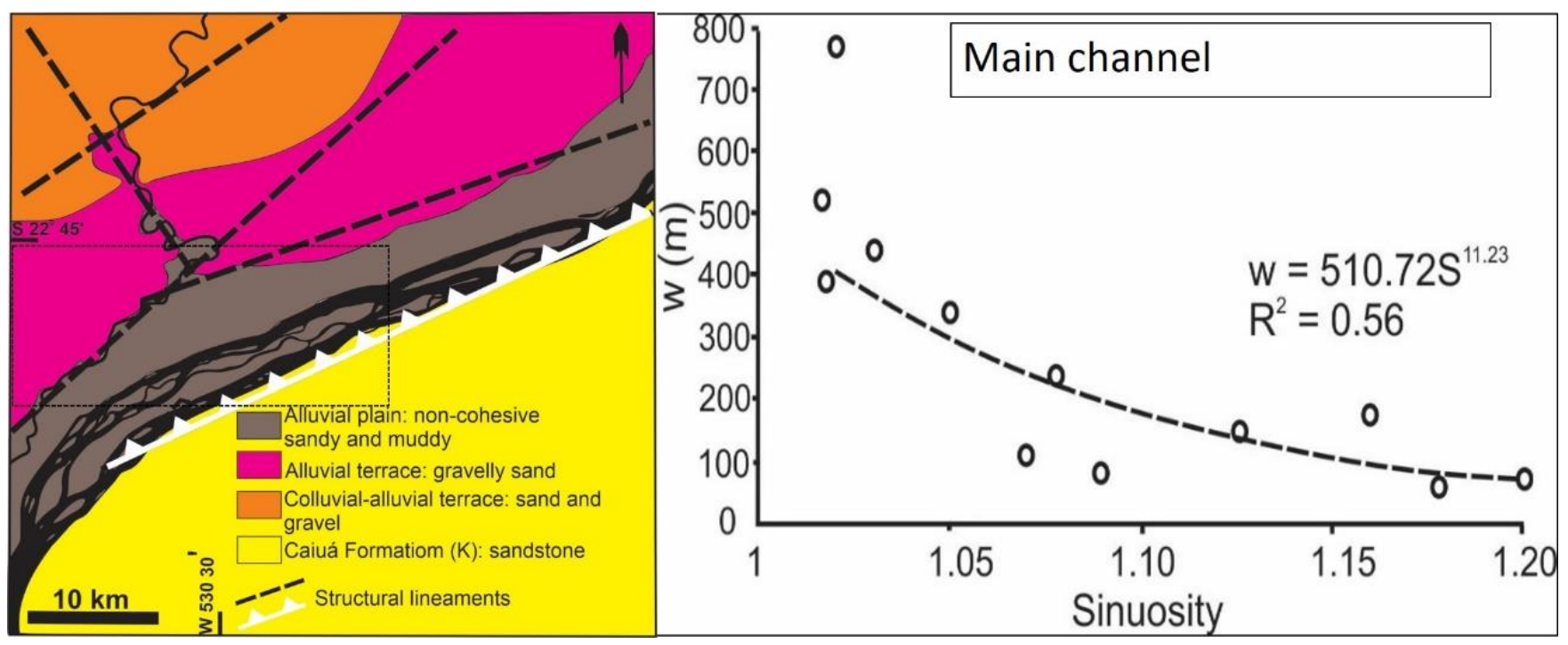

Figure 5. Left: geological and geomorphological map of the study reach. The generally straight pattern of the river channel results from the erosion-resistant sandstone of the Caiuá Formation and the normal NW fault in the left bank (see Figure 8 for details). Right: sinuosity versus channel width.

The morphological characteristics of the reach are presented in Figure 6. The river in the study reach has an anabranching channel pattern defined by two nodal sections (S1 and S14), where it is possible to identify a downstream trend of increasing size and quantity of islands.

The alluvial plain (floodplain + channel) varies in width downstream. In the first $20 \mathrm{~km}$, the alluvial plain is 7,000 to $8,000 \mathrm{~m}$ in width, and it gradually increases up to $10,500 \mathrm{~m}$ from 30 to $47 \mathrm{~km}$.

The floodplain is wider than the river channel throughout the whole segment and varies from 3,000 to 6,000 $\mathrm{m}$. The wider segments of the floodplain $(25$ to $47 \mathrm{~km}$ ) correspond to the confluence of the right bank tributary, the Ivinhema River.

The anabranching degree is the number of channels in a section. It increases downstream from 1 (S1 and S14) to 6 (S11 and S13) channels per section. The highest anabranching degree values are in the last $12 \mathrm{~km}$ of the stretch (from 40 to $52 \mathrm{~km}$ ).

River width (distance between left and right banks, including channels and islands) increases with an anabranching degree: $1,250 \mathrm{~m}$ at nodal $\mathrm{S} 1,3000 \mathrm{~m}$ at $\mathrm{S} 3,4,500 \mathrm{~m}$ at $\mathrm{S} 4$, and a maximum of 5,000 to 6,000 $\mathrm{m}$ in the Ivinhema River confluence area at S9, S10, S11, and S12.

Channel width ( $\Sigma \mathrm{w}$ of the channels in a section) does not present the same tendency, remaining approximately constant from S2 to S13.

Island width ( $\Sigma$ islands' widths) increases up to 2.6 times the anabranching degree.

The main channel (a wider channel) occurs in all sections; however, its width is lower than the sum of the secondary channels (except for S5). In all these sections, the main channel discharge does not exceed $30 \%$ of those of the secondary channels.

The sum of the secondary channels' widths increases very little downstream, without any marked tendency, but shows a good correlation with river channel width.

The sum of the islands' widths increases approximately $50 \%$ downstream. 


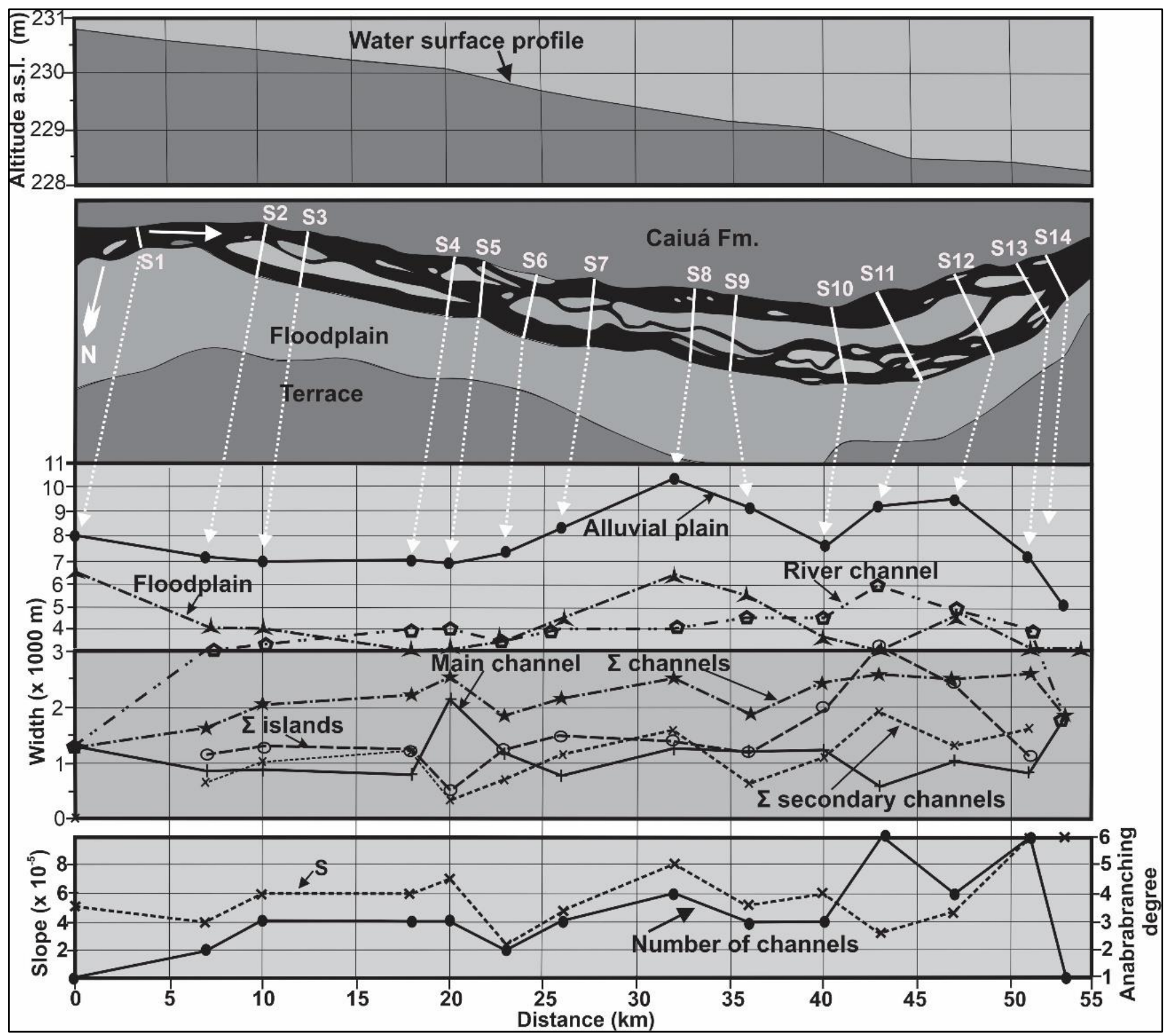

Figure 6. Morphological characteristics of the anabranching study reach of the Upper Paraná River. S1 to S14 are the surveyed cross-sections; Alluvial plain = channel + floodplain width; River channel = distance between left and right river banks; $\Sigma$ channel = main + secondary channel width; Main channel $=$ width of main channel; $\Sigma$ islands = sum of islands' widths; $\Sigma$ secondary channel $=$ sum of secondary channels' widths.

\subsection{Channel morphology and hydraulics}

The results of morpho-hydraulic surveys for each section are presented in Table 2.

Table 2. Synthesis of morpho-hydraulic variables of the study sections.

\begin{tabular}{|c|c|c|c|c|c|c|c|c|c|c|c|c|c|}
\hline$S$ & $\mathrm{~km}$ & $\begin{array}{l}s \\
\left(10^{-5}\right)\end{array}$ & $\begin{array}{l}v \\
\left(m s^{-1}\right)\end{array}$ & $\begin{array}{l}w \\
(m)\end{array}$ & $\begin{array}{r}\bar{d} \\
(m)\end{array}$ & $\begin{array}{l}R h \\
(m)\end{array}$ & $w: d$ & $\begin{array}{l}\text { w:d } \\
\text { average }\end{array}$ & $\begin{array}{l}Q \\
m^{3} s^{-1}\end{array}$ & $\begin{array}{l}\Omega c \\
\left(W m^{-1}\right)\end{array}$ & $\begin{array}{l}\Omega s \\
\left(W m^{-1}\right)\end{array}$ & $\begin{array}{l}\omega \\
\left(W m^{-2}\right)\end{array}$ & $\begin{array}{c}\bar{\omega} \\
\left(W m^{-2}\right)\end{array}$ \\
\hline 1 & 0 & 5 & 1.50 & 1250,23 & 5,37 & 5.35 & 232,77 & 232,77 & 10386 & 5000 & 5000 & 4.00 & 4.00 \\
\hline $2 A$ & & 4 & 0.68 & 946,55 & 3,87 & 3.85 & 244,53 & 222,26 & 8083 & 3122 & 6079 & 3.30 & 3.54 \\
\hline $2 B$ & 7 & 8 & 1.15 & 774,02 & 3,87 & 3.85 & 200,00 & & 2240 & 2957 & & 3.82 & \\
\hline $3 A$ & & 4 & 0.68 & 991,22 & 3,87 & 3.85 & 256,13 & & 7241 & 2845 & & 2.87 & \\
\hline
\end{tabular}




\begin{tabular}{|c|c|c|c|c|c|c|c|c|c|c|c|c|c|}
\hline $3 B$ & & 5 & 0.76 & 253,01 & 3,87 & 3.81 & 65,37 & 173,52 & 577 & 284 & 4508 & 1.12 & 2.37 \\
\hline $3 C$ & 9 & 6 & 0.80 & 770,32 & 3,87 & 3.85 & 199,05 & & 2136 & 1379 & & 1.79 & \\
\hline $4 \mathrm{~A}$ & & 7 & 0.98 & 379,25 & 4,87 & 4.81 & 77,871 & & 1809 & 1244 & & 3.28 & \\
\hline $4 B$ & & 6 & 1.07 & 869,43 & 5,87 & 5.83 & 148,11 & 147,90 & 5319 & 3478 & 6222 & 4.00 & 3.00 \\
\hline $4 C$ & 17 & 7 & 0.84 & 842,64 & 3,87 & 3.85 & 217,73 & & 2105 & 1500 & & 1.78 & \\
\hline $5 A$ & & 5 & 0.85 & 413,27 & 4,62 & 4.57 & 89,45 & & 1553 & 880 & & 2.13 & \\
\hline $5 B$ & 19 & 7 & 0.84 & 100,52 & 3,62 & 3.49 & 27,62 & & 5319 & 166 & 5096 & 1.65 & 2.03 \\
\hline $5 C$ & & 6 & 0.96 & 1994,31 & 5,37 & 5.36 & 403,41 & 173,49 & 2105 & 4050 & & 2.03 & \\
\hline $6 A$ & & 3 & 0.92 & 726,64 & 8,12 & 8.03 & 89,49 & & 4925 & 1533 & & 2.11 & \\
\hline & 21 & & 1,02 & & & 4.35 & & 167,46 & 4557 & 4065 & 5598 & 3.79 & 3.15 \\
\hline $6 B$ & & 9 & & 1072,52 & 4,37 & & 245,43 & & & & & & \\
\hline $7 A$ & & 5 & 1.08 & 899,35 & 7,12 & 7.06 & 126,31 & & 4650 & 2279 & & 2.69 & \\
\hline $7 B$ & & 8 & 0.76 & 2429,1 & 2,37 & 2.34 & 82,05 & & 211 & 165 & 6459 & 1.44 & 3.27 \\
\hline $7 C$ & 24 & 8 & 1.04 & 979,24 & 4,62 & 4,60 & 211,96 & 102,11 & 7712 & 4015 & & 4.10 & \\
\hline $8 \mathrm{~A}$ & & 8 & 0.96 & 1249,39 & 4,37 & 4.35 & 285,90 & & 4825 & 3798 & & 3.04 & \\
\hline $8 B$ & & 6 & 0.67 & 162,79 & 2,87 & 2.82 & 56,72 & & 245 & 164 & 6282 & 1.01 & 2.53 \\
\hline $8 C$ & & 8 & 1.00 & 283,66 & 4,62 & 4.55 & 61,40 & & 816 & 646 & & 2.28 & \\
\hline $8 D$ & 30 & 4 & 0.92 & 774,99 & 6,12 & 6.07 & 126,63 & 132,67 & 3620 & 1674 & & 2.16 & \\
\hline $9 A$ & & 5 & 1.02 & 1182,53 & 6,37 & 6.34 & 185,64 & & 4900 & 2636 & & 2.23 & \\
\hline $9 B$ & & 6 & 0.81 & 116,34 & 3,87 & 3.74 & 30,06 & & 206 & 136 & 6355 & 1,17 & 2.88 \\
\hline $9 C$ & 32 & 7 & 1.16 & 1060,74 & 5,87 & 5.84 & 189,70 & 135,13 & 4633 & 3583 & & 3.38 & \\
\hline $10 A$ & & 6 & 0.97 & 1174,1 & 5,37 & 5.35 & 218,66 & & 4658 & 2794 & & 2.38 & \\
\hline $10 B$ & & 7 & 1.03 & 515,02 & 4,87 & 4.82 & 105,75 & & 2171 & 1679 & 6001 & 3.26 & 2.64 \\
\hline $10 \mathrm{C}$ & 38 & 6 & 1.04 & 579,8 & 5,87 & 5.81 & 98,77 & 141,06 & 2487 & 1528 & & 2.63 & \\
\hline $11 A$ & & 5 & 0.86 & 610,31 & 4,87 & 4.83 & 125,32 & & 1737 & 933 & & 1.53 & \\
\hline $11 B$ & & 3 & 0.97 & 438,4 & 7,62 & 7.49 & 57,53 & & 3376 & 1288 & & 2.94 & \\
\hline $11 C$ & & 8 & 1.27 & 479,18 & 5,37 & 5.31 & 89,22 & & 1920 & 2002 & 6810 & 4.18 & 2.92 \\
\hline $11 D$ & & 8 & 1.13 & 319,4 & 5,12 & 5.04 & 62,38 & & 1344 & 1180 & & 3.70 & \\
\hline $11 E$ & 41 & 8 & 1.06 & 383,57 & 3,87 & 3.83 & 99,11 & 75,43 & 1060 & 1222 & & 3.19 & \\
\hline $11 F$ & & 3 & 0.79 & 109,9 & 5,79 & 5.50 & 19,00 & & 509 & 185 & & 1.70 & \\
\hline $12 A$ & & 4 & 0.58 & 104,66 & 3,37 & 3.26 & 31,05 & & 209 & 84 & & 0.81 & \\
\hline $12 B$ & & 5 & 0.97 & 918,85 & 5,87 & 5.83 & 156,53 & & 4737 & 2554 & 7432 & 2.78 & 3.12 \\
\hline $12 C$ & & 9 & 1.03 & 344,1 & 4,12 & 4.07 & 85,52 & 126,18 & 920 & 898 & & 2.61 & \\
\hline $12 D$ & 45 & 9 & 1.13 & 1012.2 & 4.37 & 4.35 & 231.63 & & 3594 & 3896 & & 3.85 & \\
\hline $13 A$ & & 9 & 0.46 & 902,58 & 7,12 & 7.06 & 126,77 & & 4621 & 4059 & & 4.50 & \\
\hline $13 B$ & & 3 & 0.79 & 72,88 & 5,87 & 5.43 & 12,41 & & 350 & 102 & & 1.40 & \\
\hline $13 C$ & & 3 & 0.79 & 656,86 & 6,37 & 6.31 & 103,12 & 76,1 & 936 & 269 & 6919 & 0.41 & 2.68 \\
\hline $13 D$ & & 6 & 0.96 & 481,42 & 4,87 & 4.82 & 98,85 & & 1718 & 1174 & & 2.44 & \\
\hline $13 E$ & 48 & 9 & 0.86 & 269,4 & 3,37 & 3.33 & 79,94 & & 591 & 527 & & 1,96 & \\
\hline $13 F$ & & 5 & 0.978 & 202,6 & 5,87 & 5.70 & 35,51 & & 1453 & 788 & & 3.90 & \\
\hline 14 & 50 & 7 & 1.17 & 1954,99 & 5,37 & 5.36 & 368,85 & 368,85 & 9640 & 7558 & 7558 & 4.38 & 4.38 \\
\hline
\end{tabular}


The general slope of the reach (S1 to S14) is 0.00006, with variations between 0.00003 and 0.00009 . Values obtained by Eq. 1 are quite similar to those obtained through conventional topography (MATONI and LESSA, 1999) and DGPS (LELI, 2015) for the same reach (Table 3). It remained relatively constant along the stretch, regardless of the number of channels for each section (Figure 6).

Table 3. Water surface slope from different sources.

\begin{tabular}{|c|c|c|c|}
\hline \multirow[b]{2}{*}{ Reach } & \multirow[b]{2}{*}{ Manning equation* } & \multicolumn{2}{|c|}{ Slope $\left(\mathrm{cm} \mathrm{km}^{-1}\right)$} \\
\hline & & Topographic Survey ${ }^{* *}$ & DGPS Survey $^{* * *}$ \\
\hline $\mathrm{S} 1-\mathrm{S} 2$ & 4.0 & 2.0 & \multirow{6}{*}{$3.4-3.5$} \\
\hline $\mathrm{S} 2-\mathrm{S} 3$ & 7.0 & 5.4 & \\
\hline $\mathrm{S} 3-\mathrm{S} 4$ & 7.5 & 7.3 & \\
\hline S4 - S5 & 6.0 & 3.5 & \\
\hline $\mathrm{S} 5-\mathrm{S} 6$ & 4.5 & 13.4 & \\
\hline S6 - S7 & 4.0 & 2.0 & \\
\hline S7 - S8 & 6.5 & 5.8 & \multirow{5}{*}{$5.3-5.9$} \\
\hline S8 - S9 & 7.0 & 6.1 & \\
\hline S10 - S11 & 6.0 & 7.6 & \\
\hline S11 - S12 & 4.5 & 1.8 & \\
\hline S12 - S14 & 6.0 & 3.4 & \\
\hline Slope average & 5.7 & 5.3 & 4.5 \\
\hline
\end{tabular}

*From Table 2; ${ }^{* *}$ Martoni and Lessa (1999); ${ }^{* * *}$ Leli (2015).

The relation w: d decreases with increasing anabranching degree (Figure 6). The multiple channels showed $\omega$ ranging from $0.41 \mathrm{~W} \mathrm{~m}^{-2}$ in section $13 \mathrm{C}$ to $4.50 \mathrm{~W} \mathrm{~m}^{-2}$ in section $13 \mathrm{~A}$. However, the $\omega$ average by section remained relatively constant between 2.0 to $3.0 \mathrm{~W} \mathrm{~m}^{-2}$ regardless of variations in the number of channels (Figure 6). In S1 and S14, nodal sections presented $\omega$ values of 4.00 and $4.38 \mathrm{~W} \mathrm{~m}^{-2}$, respectively. $\Omega$ in each section varied from 4508 to $7432 \mathrm{~W} \mathrm{~m}^{-1}$; however, it slightly increased with the number of channels (Figure 6). Sections with 1 to 3 channels presented an average $\Omega$ from 6000 to $6860 \mathrm{~W} \mathrm{~m}^{-1}$. We attribute this variation to local hydraulic conditions during the survey. 


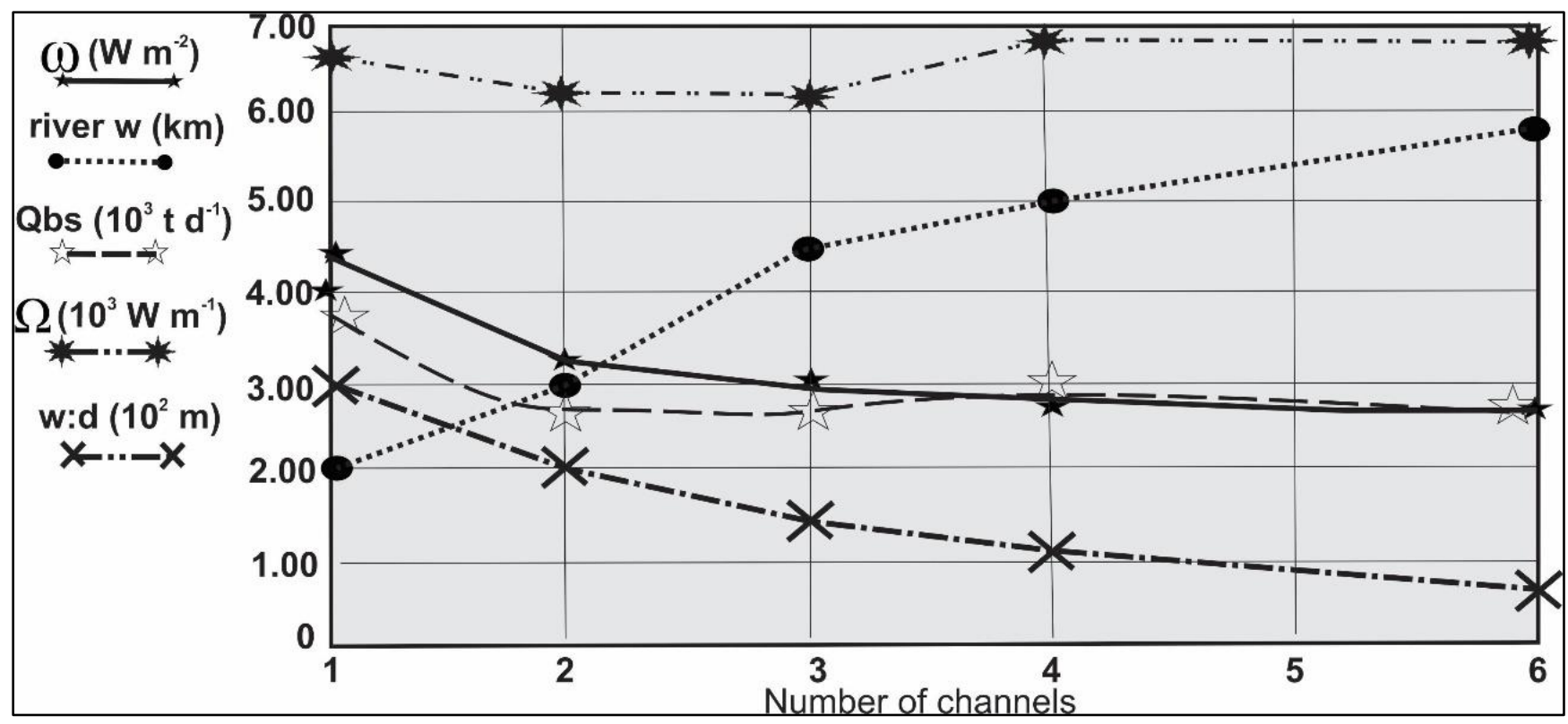

Figure 7. Relation between morphological and hydraulic variables. The ratio w:d decreases (the channels become narrower and deeper) as river $\mathrm{w}$ increases with the increasing number of channels. Except for the nodal sections, $\mathrm{t}$ hydraulic variables remain relatively constant regardless of the number of channels (river $\mathrm{w}=$ distance between river banks, including islands).

Although qb varies from zero to $4.3210^{-5} \mathrm{~m}^{3} \mathrm{~s}^{-1} \mathrm{~m}^{-1}$ in the reach's channels, $\mathrm{Qbs}$ is much more regular, varying from 2059 to $3815 \mathrm{t} \mathrm{d}^{-1}$ (Table 4). These values are very consistent with those obtained using the dune shifting methods by Martins (2008) and Stevaux et al. (2009). We estimated Qbc in the nodal sections S1 and S14 at 2820 and $3150 \mathrm{t} \mathrm{d}^{-1}$, respectively. Some channels presented no transport $\left(\mathrm{Qbc}=0.00 \mathrm{~m}^{3} \mathrm{~s}^{-1} \mathrm{~m}^{-1}\right)$. In these cases, we verified that they had a bed-load grain diameter above the threshold for transport defined by Shield (1936 apud SANTOS et al., 2017).

Table 4. Synthesis of bed load transport calculations.

\begin{tabular}{|c|c|c|c|c|c|c|c|}
\hline Section & $q b$ & Qbc & Qbs & Section & $q b$ & Qbc & Qbs \\
\hline 1 & 2.2 & 3777 & 3777 & $9 \mathrm{~A}$ & 2.12 & 2166 & \multirow{3}{*}{2188} \\
\hline $2 \mathrm{~A}$ & 0.94 & 1196 & \multirow{2}{*}{2676} & 9B & 0.22 & 22 & \\
\hline $2 B$ & 1.91 & 1.480 & & $9 \mathrm{C}$ & 0.00 & 0 & \\
\hline $3 \mathrm{~A}$ & 0.81 & 1102 & \multirow{3}{*}{2277} & $10 \mathrm{~A}$ & 0.69 & 670 & \multirow{3}{*}{2592} \\
\hline $3 B$ & 0.68 & 149 & & 10B & 4.32 & 1922 & \\
\hline $3 C$ & 0.97 & 1026 & & $10 \mathrm{C}$ & 0.00 & 0 & \\
\hline $4 \mathrm{~A}$ & 0.30 & 156 & \multirow{3}{*}{2919} & $11 \mathrm{~A}$ & 0.85 & 448 & \multirow{6}{*}{2360} \\
\hline $4 B$ & 2.96 & 2224 & & 11B & 1.09 & 516 & \\
\hline $4 C$ & 0.74 & 539 & & $11 \mathrm{C}$ & 0.00 & 0 & \\
\hline $5 \mathrm{~A}$ & 0.80 & 286 & \multirow{3}{*}{2938} & 11D & 0.00 & 0 & \\
\hline $5 B$ & 0.25 & 22 & & $11 \mathrm{E}$ & 4.03 & 1353 & \\
\hline $5 C$ & 1.07 & 2630 & & $11 \mathrm{~F}$ & 0.48 & 43 & \\
\hline $6 \mathrm{~A}$ & 1.81 & 1136 & \multirow{2}{*}{2710} & $12 \mathrm{~A}$ & 0.08 & 7 & \multirow{3}{*}{3207} \\
\hline $6 B$ & 1.70 & 1574 & & 12B & 1.21 & 961 & \\
\hline $7 \mathrm{~A}$ & 0.80 & 988 & & $12 \mathrm{C}$ & 1.50 & 446 & \\
\hline
\end{tabular}




\begin{tabular}{|c|c|c|c|c|c|c|c|}
\hline 7B & 0.03 & 4 & \multirow[t]{2}{*}{2524} & 12D & 2.05 & 1793 & \\
\hline $7 \mathrm{C}$ & 1.97 & 1532 & & 13A & 0.14 & 109 & \multirow{5}{*}{2514} \\
\hline $8 \mathrm{~A}$ & 1.27 & 2126 & \multirow{5}{*}{2889} & 13B & 0.80 & 79 & \\
\hline $8 B$ & 0.00 & 0 & & $13 \mathrm{C}$ & 0.65 & 585 & \\
\hline $8 C$ & 0.00 & 0 & & 13D & 2.98 & 1691 & \\
\hline \multirow[t]{3}{*}{$8 \mathrm{D}$} & 1.14 & 763 & & $13 \mathrm{E}$ & 0.12 & 50 & \\
\hline & & & & $13 \mathrm{~F}$ & 1.14 & 316 & \\
\hline & & & & 14 & 2.26 & 3815 & 3815 \\
\hline
\end{tabular}

Unitary bed-load discharge ( $\mathrm{qb}$ ) is given in units of $10^{-5} \mathrm{~m}^{3} \mathrm{~s}^{-1} \mathrm{~m}^{-1}$. The bed-load discharge by channel $\left(\mathrm{Qbc}\right.$ in $\left.\mathrm{t} \mathrm{d}^{-1}\right)$ is given by $\mathrm{qb}^{*} \mathrm{w}^{*} \mathrm{k} . \mathrm{Q}$, where $\mathrm{n}$ is each channel of a section, $\mathrm{k}=86400$ is the correction factor for daily discharge, and $\mathrm{Q}$ is the density of river sand $=2650 \times 0.6=1590 \mathrm{~kg} \mathrm{~m}^{-3}$. Bed-load discharge by section (Qbs; in $\mathrm{t} \mathrm{d}^{-1}$ ) is given by $\sum_{1}^{\mathrm{n}} \mathrm{Qbc}$ (sum of Qbc of a section).

\section{Discussion}

This discussion can be initiated with two assumptions: (1) the nodal sections S1 and S14 present $\omega$ and qb greater than multichannel sections, and (2) the anabranching degree increases with river w. The immediate question is why the river does not remain as a single channel if it is more effective? Firstly, we could state that river anabranching is due to channel enlargement, which is probably related to allochthonous causes:

1) The first is a structural cause: the regional NW Rio Alonzo Lineament System crosses a local NE structural lineament near the area where the Ivinhema River enters the Paraná River's floodplain, between S7 and S 10 (Figures 3 and 5). The Ivinhema River flows SE to the Paraná River floodplain and runs parallel to the trunk river for more than $25 \mathrm{~km}$. The alluvial plain at this site is a large, triangular low area - a tectonic bloc according to Fortes et al., 2005, 2007, with many lakes and swamps (Figure 7). The Paraná channel enlarges by $35 \%(\mathrm{w}=6 \mathrm{~km})$ and presents up to 6 channels per section.

2) Another factor for channel $w$ enlargement is the bank lithology. The left river banks formed by sandstone are stable at the timescale of the present alluvial plain ( $10^{4}$ years), so the river channel cannot be enlarged at this side. The right bank is formed by muddy or mixed sandy-muddy alluvial deposits. Muddy banks are cohesive, which increases their resistance to erosion. The nodal sections S1 and S14 are probably controlled by the muddy constitution of the banks on the right bank. On the other hand, the wider multichannel sections generally present a mixed composition formed by sand and clay, which is more erodible. A NW normal fault has produced a rectilinear bank along with the majority of the study stretch (Figures 5 and 8). 


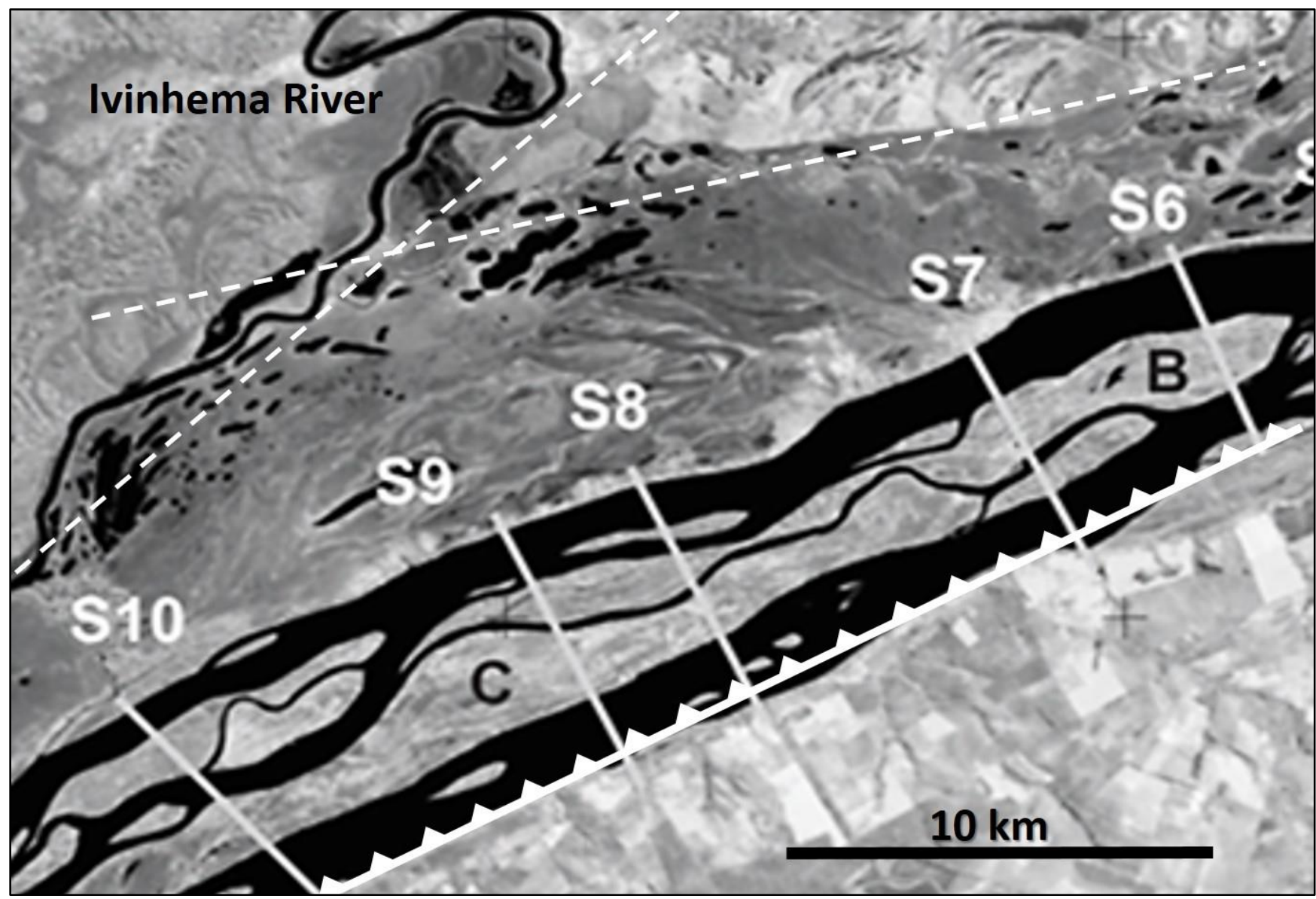

Figure 8. Sections with a wider alluvial plain and a greater number of channels (S6 to S10) are at the intersection of structural lineaments. Fortes et al. $(2005,2007)$ suggested that the occurrence of this wide, low floodplain with many water bodies is the result of a lowered tectonic block. See Figure 5 for localization.

Once the channel is widened and the flow is maintained, the flow loses its specific power (Eq. 3) and its efficiency in carrying out erosion, transport, and sedimentation. The increase in specific stream power would be due to an increase in the slope and/or a reduction in the width of the channel. As observed in this work (Figure 7), the slope remained practically constant throughout the stretch, regardless of the anabranching index. Thus, the maintenance of the flow efficiency results from the reduced width caused by the generation of islands. The sum of the multiple channels in each section is the same for the entire reach (Figure 7). In this way, the system seeks to maintain the same width so that $\omega$ is maintained. Once the width is reduced, the area of the channel section is maintained by increasing the depth, and the channels become narrower and deeper. This mechanism is evident in this study from the inverse relationship between the anabranching index and the w:d ratio (Figure 6). $\Omega$ also remains constant, once the discharge is maintained, and $\mathrm{s}$ does not change significantly (Figure 6).

The efficiency maintenance was also observed for sediment transport, although the highest Qbs values were observed in both nodal sections (S1 and S2). The Qbc data suggest that sediments are partly retained in sections with the highest anabranching. Comparing stretches with sections from 1 to 3 channels with those with 6 channels per section, we find a larger number of sand bars in the second group (Figure 9). This fact is consistent with the behavior of the specific channel power data discussed above. 


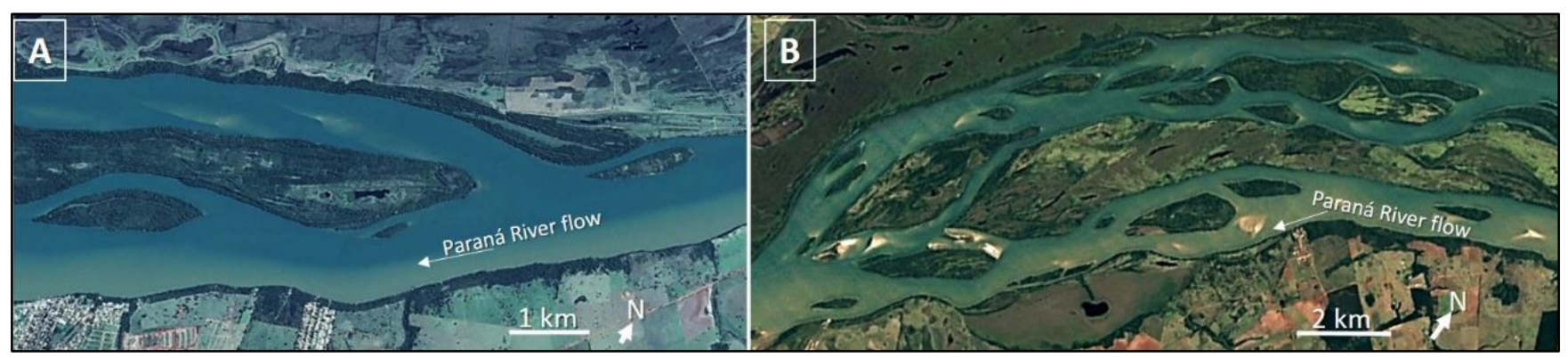

Figure 9. Comparison of stretches with low (A) and high (B) anabranching index. The second group presents a high number of sand bars, suggesting more active sedimentation and less efficiency of bed-load transport.

\section{Conclusions}

1. The anabranching pattern, in this case, generated by in-channel processes, occurs to maintain the hydraulic efficiency of the channel in the wider stretches of the river.

2. The flow maintains its efficiency along longer reaches by increasing the slope and/or reducing the w: $\mathrm{d}$ ratio. In the studied case, the system reduced the $\mathrm{w}: \mathrm{d}$ ratio, as the slope did not change significantly throughout the stretch. 3. Thus, when multiple channels have higher values of $\mathrm{w}: \mathrm{d}$ the higher their anabranching indexes.

4. The nodal sections presented an energetic efficiency 30\% higher than the multiple sections, observed not only in the specific stream power and Qbc but also by the lower number of sand bars in the channel when compared to multichannel sections.

5. Channel widening, in the case studied, is controlled by allochthonous factors, mainly linked to the bank composition, and secondarily to the occurrence of structural lineaments.

Financing: The authors thank the National Council of Science and Technology - CNPq for funding the research through the CNPq processes 304863/2015-7 (Jose C. Stevaux) and CNPq processes 405190/2018-2 (Isabel T. Leli).

Acknowledgment: The authors would like to thank the Núcelo de Pesquisa em Liminologia, Ictiologia e Aquicultura - NUPELIA for fieldwork support, and the Grupo de Estudos Multidisciplinares do Ambiente GEMA of the State University of Maringá - UEM.

Conflict of interest: The authors declare no conflict of interest. Funders did not interfere in the development of the study, in the collection, analysis, or interpretation of data, in the writing of the manuscript, or in the decision to publish the results.

\section{References}

1. ABBADO, D., SLINGERLAND, R., SMITH, N.D. Origin of anastomosis in the upper Columbia River, British Columbia, Canada. In BURN, M., MARIOTT, S. and LECLAR, S. (Eds.), Fluvial Sedimentology. VII Spec. Publ. Int. Ass. Sedimentology. 2005. 35:3-15.

2. ALMEIDA, F.F.M. The system of Continental Rift bordering the Santos Basin, Brazil. Anais da Academia Brasileira de Ciências, 48 (supl.), p. 15-26, 1976.

3. AMSLER, M.L., PRENDES, H.H., ROMANO, C.F. Características de grandes dunas observada en el rio Paraná. In: XIX Congresso Latinoamericano de Hidráulica, Anais... Córdoba, Argentina v. I. p. 329-338, 2000. 4

4. BAGNOLD, R.A. An approach to the sediment transport problem from general physics. U.S. Geol. Survey Prof. Paper, 422-I, 1966. 
5. BAGNOLD, R.A. Bed load transport by natural rivers. Water Resources Research, v.13, p. 303-312, 1977.

6. COMUNELLO, E., SOUZA FILHO, E.E., ROCHA, P.C. Dinâmica de inundação de áreas alagáveis na planície aluvial do alto rio Paraná. Boletim Paranaense de Geociências, Curitiba, 49:61-82, 2002.

7. CORRÊA, G.T.; SOUZA FILHO, E.E., 2005. Avaliação dos Processos de Erosão Marginal no Arquipélago Floresta Japonesa (Alto rio Paraná) no período de 1952 a 1996. Acta Scientiarum (UEM), v. 26, p. 1-22, 2005.

8. DIETRICH, W., DAY, G., PARKER, G. (1999). The Fly River, Papua New Guinea: inferences about river dynamics, floodplain sedimentation and fate of sediment. In: MILLER, A., GUPTA, A. (Eds.), Varieties of Fluvial Forms, Wiley, pp. 345-376.

9. FERNANDEZ, O.V.Q. Mudanças no canal fluvial do rio Paraná e processos de erosão nas margens: região de Porto Rico, PR. Dissertação (Mestrado em Geologia). UNESP/IGCP/Rio Claro, 1990.

10. FILIZOLA, N.; GUYOT, J. L. Suspended sediment yields in the Amazon basin: an assessment using the Brazilian national data set. Hydrological Processes, v. 23, p. 3207-3215, 2009.

11. FORTES, E., STEVAUX, J.C., VOLKMER, S. Neotectonics and channel evolution of the lower Ivinhema River, A right-bank tributary of the upper Paraná River, Brazil. Geomorphology, v. 70, p. 325-338, 2005.

12. FORTES, E., VOLKMER, S., STEVAUX, J.C., MARQUES, A.J. Anomalias de Drenagem e Controles Morfotectônicos da Evolução dos Terraços do Baixo Curso do Rio Ivinhema -MS. Geociências UNESP, Rio Claro, SP, 2007, v. 26, p. 249-261.

13. FRANCO, A.L.A., ETCHBEHERE, M.L.C., STEVAUX, J.C. Hipótese sobre os condicionantes neotectônicos do barramento natural da foz do rio Ivaí (PR) com base em levantamento ecobatimétrico. Revista Geociências UnG, v. 7. n. 1, p. 78-86, 2008.

14. FULFARO, V.J., SAAD, A.R., SANTOS, M.V., VIANNA, R.B. Compartimentação e evolução tectônica da Bacia do Paraná. Revista Brasileira de Geociências, v. 12. n. 4, p. 590-611, 1982.

15. HUANG, H.Q., NANSON, G.C. Hydraulic geometry and maximum flow efficiency as products of the principle of least action, Earth Surf. Processes Landforms, v. 25, p. 1-13, 2000.

16. HUANG, H.Q., NANSON, G.C. Why some alluvial rivers develop an anabranching pattern, Water Resour. Res., v. 43, 2007. W07441, doi:10.1029/2006WR005223.

17. JANSEN, J.D., NANSON, G.C. Anabranching and maximum flow efficiency in Magela Creek, northern Australia, Water Resour. Res., v. 40, 2004. W04503, doi:10.1029/2003WR002408,

18. JANSEN, J.D., NANSON, G.C. Functional relationships between vegetation, channel morphology, and flow efficiency in an alluvial (anabranching) river. Journal of Geophysical Research - Earth Surface, v. 115, F04030, 2010.

19. KNIGHTON, A. D. Fluvial Forms and Processes: A New Perspective. London: Edward Arnold, 1998. 383p.

20. LATRUBESSE, E.M. Patterns of anabranching channels: The ultimate endmember adjustment of Mega Rivers. Geomorphology, 101:130-145, 2008.

21. LATRUBESSE, E.M., ARIMA, Y.E., DUNNE, T., PARK, E., BAKER, V.R., D'HORTA, F.M., WIGHT, C., WITTMANN, F., ZUANON, J., BAKER, P.A., RIBAS, C.C., NORGAARD, R.B., FILIZOLA, F., ANSAR, A., FLYVBJERG, B., STEVAUX, J.C., 2 Damming the rivers of the Amazon basin. Nature, v. 546, 2017. doi:10.1038/nature22333.

22. LELI. I.T. Gênese, evolução e geomorfologia das ilhas e planície de inundação do alto rio Paraná, Brasil. Tese (Doutorado em Geociências e Meio Ambiente), UNESP/IGCE/Rio Claro, Brasil, 2015.

23. LELI, I.T., STEVAUX, J.C., ASSINE, M.L. Genesis and sedimentary record of blind channel and islands of the anabranching river: An evolution model. Geomorphology, 302:35-45, 2018. doi.org/10.1016/j.geomorph.2017.05.001 
24. LELI, I.T., STEVAUX, J.C., ASSINE, M.L. Origin, evolution, and sedimentary records of islands in large anabranching tropical rivers: The case of the Upper Paraná River, Brazil. Geomorphology, v. 358, 107118, 2020. doi.org/10.1016/j.geomorph.2020.107118

25. MACEDO, H.A., STEVAUX, J.C., ASSINE, M.L., SILVA, A., PUPIM, F.N., MERINO, E.R., LO, E. Calcullating bedload transporting in rivers: Concepts, calculus routines and application. Revista Brasileira de Geomorfologia, 18:801-812, 2017.

26. MARTINELLI, L,A., VICTORIA, R.L., DEMATTE, J.L.I., RICHEY, J.E., DEVOL, A.H., Chemical and mineralogical composition of Amazon River floodplain sediments, Brazil. Applied Geochemistry, 8(4):391402, 1993.

27. MARTINS, D.P. Aménagements hydroélectriques et impacts sur la dynamique des flux d'eau et de sédiments. Le cas du haut Paraná, Brésil. Doctoral thesis in Geography, Université Lumière Lyon 2, Lyon, France, 2008.

28. MARTINS, D.P., STEVAUX, J.C. Formas e leito e transporte da carga de fundo do alto rio Paraná. Revista Brasileira de Geomorfologia, v. 6, n. 2, p. 43-50, 2005.

29. MARTONI, A.M., LESSA, R.C., Modelagem hidrodinâmica do canal do Paraná, no trecho Porto São José Porto 18. Parte I: Caracterização física do canal. Acta Scientiarum, v. 21, n. 4, p. 949-959, 1999.

30. MEADE, R.H., NORDIN JR., C.F., HERNANDEZ, D.P., MEJÍA, B.A., GODOY, J.M. Sediment and water discharge in rio Orinoco, Venezuela and Colombia. In: II International Symposium on River Sedimentation: Water Resources and Electric Power, Nanjing, China, Proceedings...1983. p. 1134-1144.

31. NANSON G.C., HUANG, H.Q. Least action principle, equilibrium states, iterative adjustment and the stability of alluvial channels. Earth Surface Processes and Landforms, v. 33, p. 923-942, 2008. doi:10.1002/esp.1584.

32. NANSON, G.C., HUANG, H. Q. Anabranching rivers: Divided efficiency leading to fluvial diversity. In: MILLER, A. J; GUPTA, A (Ed.), Varieties of Fluvial Form, p. 477- 494, Hoboken, N. J: John Wiley, 1999. p. 477-494.

33. NANSON, G.C., KNIGHTON, A. D., 1996. Anabranching Rivers: their cause, character, and classification, Earth Surf. Processes Landforms, v. 21, p. 217-239, 1996.

34. ORFEO, O., STEVAUX, J.C. Hydraulic and morphological characteristics of the middle and upper reaches of the Paraná River (Argentina and Brazil). Geomorphology, 2002, v. 44. n. 34, p. 309-322.

35. PARK, E., LATRUBESSE, E.M. Modeling suspended sediment distribution patterns of the Amazon River using MODIS data. Remote Sens. Environ, 147:232-242, 2004.

36. POTTER, P.E., HUMBLIN, W.K. Big rivers worldwide. Brigham Young University, Geology Studies, v. 46, 2006.

37. SOUZA JR., M.D., SANTOS, M.L., SALAMINI, E., STEVAUX, J.C., MORALES, N. Análise Morfotectônica Da Bacia Hidrográfica do Rio Ivaí-PR, Curso Inferior. Revista Brasileira de Geomorfologia, 14:208-211, 2013.

38. SOUZA-STEVAUX, M.C.; ROMAGNOLO, M.B.; PREVIDELlO, M.E. Florística e fitossociologia de um remanescente florestal às margens do rio Paraná, município de Porto Rico, PR. Anais... Congresso Nacional de Botânica, 46, Boletim de Resumos, The Sociedade Botânica do Brasil., 325-326, Ribeirão Preto, Brazil, 1995.

39. STEVAUX, J.C. The upper Paraná River (Brazil): Geomorphology, sedimentology and Paleoclimatology. Quaternary International, 21:143-161, 1994.

40. STEVAUX, J.C.; SOUZA, I. A., 2004. Floodplain construction in an anastomosed river. Quaternary International, 2004, 14:55-65, 2004. 
41. STEVAUX, J.C., CORRADINI, F.A., AQUINO, S. Connectivity processes and riparian vegetation of the Upper Paraná River, Brazil. Journal of South American Earth Science, v. 46, p. 113-121, 2013.

42. STEVAUX, J.C., PINTO, D., MEURER, M., 2009. Changes in a large regulated tropical river: The Paraná River downstream from the Porto Primavera Dam, Brazil, Geomorphology, 2009 doi:10.1016/j.geomorph.2009.03.015.

43. TABATA, K.K., HICKIN, E.J. Interchannel hydraulic geometry and hydraulic efficiency of anastomosing Columbia River, southeastern Britsh Columbia, Canadá. Erath Surface Processes and Landfomrs, v. 28, n. 8, p.837-852, 2003.

44. THOMAZ, S.M, AGOSTINHO, A.A., HAHN, N.S. The Upper Paraná River and its Floodplain. Leinde: Backhuys Publisher, 2004. 393p.

45. TOOTH, S., NANSON, G.C. Anabranching Rivers on the northern plains of arid central Australia. Geomorphology, 29:211-233, 1999.

46. TOOTH, S., NANSON, G.C. Forms and processes of two highly contrasting rivers in arid central Australia and implications for change-pattern discrimination and prediction. Geological Society of America Bulletin, v. 116, n. 7-8, 802-816, 2004.

47. VAN RIJN, L.C. Sediment Transport, Part I: Bed Load Transport. Journal of Hydraulic Engineering, v. 110, n. 10, ASCE, 1984.

48. WENDE, R.C., NANSON, G.R. Anabranching rivers: ridge-forming alluvial channels in tropical northern Australia. Geomorphology, v. 22, n. 205-224, 1998. 